\title{
Resiliensi Pada Single Mother Setelah Kematian Pasangan Hidup
}

\author{
Indah Permata Sari ${ }^{1}$, Ifdil ${ }^{2}$, Frischa Meivilona Yendi ${ }^{3}$ \\ ${ }^{123}$ Universitas Negeri Padang \\ *) Correspondence Author, e-mail: indahversa1998@gmail.com
}

\begin{abstract}
Peristiwa kematian pasangan hidup bisa menjadi hal yang tidak terduga bagi pasangan yang ditinggalkan. Kematian pasangan menjadi pemicu mengalami tekanan kesedihan dan emosional serta harus menerima kenyataan dengan status baru yang dimiliki yakni menjadi seorang single parent. Menjadi single parent menimbulkan banyak permasalahan baru bagi mereka yang menjalaninya, terkait masalah dalam hal ekonomi, sosial, dan urusan rumah tangga yang mana harus dikerjakan sendiri. Selain itu juga seorang single parent khususnya single mother harus mampu menjalani peran ganda sebagai ayah dan juga ibu bagi anak-anaknya. Hal ini menuntut seorang single mother memiliki kemampuan resiliensi untuk menghadapi segala persoalan. Resiliensi merupakan suatu kemampuan yang sangat dibutuhkan dalam hidup, karena kehidupan yang dijalani senantiasa diwarnai oleh ragam kondisi yang tidak dapat ditolak oleh individu baik kondisi menyenangkan ataupun sebaliknya.
\end{abstract}

Keywords: Resiliensi, single mother, kematian pasangan hidup

Article History: Received on 02/09/2019; Revised on 02/10/2019; Accepted on 03/11/2019; Published Online: 07/11/2019.

\section{PENDAHULUAN}

This is an open access article distributed under the Creative Commons Attribution License, which permits unrestricted use, distribution, and reproduction in any medium, provided the original work is properly cited. (C2019 by author.

Keluarga merupakan kelompok sosial terkecil dalam masyarakat, dalam keluargalah semua aktivitas dimulai. Soelaeman (Shochib, 2000) menyatakan bahwa keluarga adalah sekumpulan orang yang hidup bersama dalam tempat tinggal bersama dan masing-masing anggota merasakan adanya pertautan batin sehingga terjadi saling mempengaruhi, saling memperhatikan, dan saling menyerahkan diri. Kondisi dan situasi yang terjadi dalam kehidupan tidak selalu berjalan sesuai dengan harapan manusia.

Kehilangan pasangan hidup dalam hubungan perkawinan merupakan kondisi yang tidak dapat dicegah (Hurlock, 2011). Kematian merupakan salah satu realitas kehidupan manusia yang sering tidak terelakkan. Hal tersebut merupakan penyebab seseorang terpaksa harus menjalani kehidupan sebagai seorang single mother. Menjadi single mother dalam sebuah rumah tangga tentu saja tidak mudah, terlebih bagi seorang wanita yang terpaksa mengasuh anaknya seorang diri baik karena bercerai dari suaminya atau suaminya meninggal dunia. Oleh karena itu, orang tua tunggal atau single mother mudah mengalami stres psikologis (Kisworowati, 2010), emosional fisik dan kebutuhan untuk sendiri. Pada saat yang bersamaan sebagai seorang single mother di tuntut harus mampu menjalani peran ganda untuk menghadiri kebutuhan anak-anaknya. 
Banyaknya permasalahan yang dialami oleh single mother membuat mereka membutuhkan kemampuan resiliensi untuk menghadapi segala persoalan. Untuk dapat berkembang secara positif dari situasi stres, trauma dan penuh risiko, manusia membutuhkan kemampuan resiliensi yang meliputi: kecakapan untuk membentuk hubungan sosial, keterampilan dalam memecahkan masalah, keterampilan mengembangkan otonomi, dan perencanaan dan pengharapan di masa depan (Werner \& Smith (Desmita, 2012)). Resiliensi bukan hanya kemampuan untuk bertahan dalam kondisi kesulitan, namun juga sebagai upaya untuk mengatasi dan menyembuhkan diri dari kondisi tertekan.

\section{RESILIENSI}

Resiliensi secara etomilogis resiliensi diadaptasi dari kata dalam bahasa inggris resilience yang berarti daya lenting atau kemampuan untuk kembali dalam bentuk semula (Novianti, 2018; Pratitasari, 2016; Ririn, 2018; W.J.S. Poerwadarminta, 2009). Redl pada tahun 1969 dan digunakan untuk menggambarkan bagian postif dari perbedaan individual dalam respon seseorang terhadap stres dan keadaan yang merugikan (adversity) lainnya (Lestari \& Mariyati, 2016). Reivich \& Shatte (Ifdil \& Taufik, 2012) menjelaskan bahwa resiliensi merupakan kemampuan untuk mengatasi dan beradaptasi dari kejadian yang berat atau masalah yang dialami dalam kehidupan. Individu dapat dikatakan memiliki resiliensi yang baik apabila dapat bertahan dalam kondisi yang tertekan atau menghadapi kesengsaraan lebih jauh bisa mengatasi trauma yang dialami dalam kehidupannya.

Senada dengan itu Holaday (1997) menyatakan bahwa individu yang memiliki resiliensi akan mampu untuk kembali kepada keadaan sebelum kejadian berat, kesengsaraan atau bahkan trauma yang pernah dialaminya serta mampu beradaptasi terhadap kondisi berat yang dialaminya. Dalam kehidupan seseorang tidak akan lepas dari yang namanya masalah ataupun kesulitan dan tidak ada orang yang hidup tanpa pernah mengalami suatu masalah atau beban berat yang mempengaruhi kondisi psikologis, oleh karenanya resiliensi menurut Grotberg (1999) merupakan kemampuan seseorang untuk menilai, mengatasi dan meningkatkan diri ataupun mengubah dirinya dari keterpurukan atau kesengsaraan dalam hidup.

Resiliensi merupakan suatu kemampuan yang sangat dibutuhkan dalam hidup, karena kehidupan yang dijalani senantiasa diwarnai oleh ragam kondisi yang tidak dapat ditolak oleh individu baik kondisi menyenangkan ataupun sebaliknya. Kondisi sulit yang dialami individu dapat menjadi tantangan bagi individu untuk dapat mengatasinya, untuk belajar darinya dan bahkan untuk merubah kondisi kehidupan sebelumnya. Resiliensi dianggap sebagai kekuatan dasar yang menjadi fondasi dari semua karakter positif dalam membangun kekuatan emosional dan psikologikal individu (Dianthoni, 2018; Fauziyyah, 2019; Lestari \& Mariyati, 2016; SETYANINGRUM, 2018).

Dari berbagai pengertian resiliensi yang telah dipaparkan di atas dapat disimpulkan bahwa resiliensi adalah kemampuan seseorang untuk bertahan dalam keadaan sulit dalam kehidupannya, beradaptasi dengan keadaan yang dialaminya dan berusaha kembali untuk kepada keadaan sebelumnya atau menjadi lebih baik. 


\section{ASPEK-ASPEK RESILIENSI}

Reivich dan Shatte (Ifdil \& Taufik, 2012) mengemukakan tujuh kemampuan dalam membentuk resiliensi, yakni meliputi :

\section{Emotion regulation}

Regulasi emosi yang merupakan kemampuan untuk tetap tenang walaupun dalam kondisi yang menekan. Keterampilan yang dapat membantu individu dalam melakukan regulasi emosi, yakni tenang dan fokus. Kedua keteramppilan ini akan membantu individu untuk meregulasi emosi, menjaga pikiran ketika banyak hal-hal yang mengganggu, serta mengurangi stress yang dialami oleh individu.

2. Impulse Control

Pengendalian impul merupakan kemampuan individu untuk dapat mengontrol keinginan, dorongan, kesukaan serta tekanan yang muncul dari dalam diri sendiri. individu memiliki kemampuan pengendalian impuls yang rendah akan cepat mengalami perubahan emosi yang pada akhirnya mengendalikan pikiran dan perilaku mereka.

3. Optimism

Optimisme merupakan kemampuan melihat masa depan yang cemerlang. Dengan memiliki aspek optimisme dalam hidup akan membuat individu percaya pada dirinya bahwa ia memiliki kemampuan untuk mengatasi segala kondisi ataupun tekanan yang mungkin terjadi di masa depan. Perpaduan antara optimisme yang realistis dan self-efficacy adalah kunci resiliensi dan kesuksesan

4. Causal analysis

Causal analysis merujuk pada kemampuan individu untuk mengidentifikasi penyebab dari permasalahan yang dihadapi. Apabila individu tidak dapat mengindentifikasi penyebab dari permasalahan yang dialami maka hal ini akan mengakibatkan individu secara terus menerus berbuat kesalahan yang sama.

5. Emphaty

Empati merupakan kemampuan individu untuk membaca tanda-tanda kondisi emosional dan psikologi orang lain. Individu yang memiliki kemampuan berempati cenderung memiliki hubungan sosial yang positif. Sedangkan individu dengan empati yang rendah cenderung akan melakukan pengulangan pola yang dilakukan oleh individu yang resilien, yakni menyamaratakan semua keinginan dan emosi orang lain.

6. Self efficacy

Self efficacy adalah kemampuan individu dalam memecahkan masalah. Dengan yang tinggi, maka individu akan melakukan berbagai usaha dalam menyelesaikan sebuah permasalahan. Dengan kemampuan dalam menyelesaikan permasalahan, individu akan dapat mencari penyelesaian masalah yang ada, dan tidak mudah menyerah terhadap berbagai kesulitan.

7. Reaching out

Reaching out merupakan kemampuan individu keluar dan meraih aspek positif dari kehidupan setelah mengalami kondisi kemalangan yang terjadi di dalam hidup. Kemampuan individu melakukan reaching out dipengaruhi 
bagaimana ia di latih sejak kecil untuk dapat menghindari kegagalan dan situasi yang memalukan.

\section{FAKTOR-FAKTOR YANG MEMPENGARUHI RESILIENSI}

Kemampuan individu dapat melakukan resiliensi dipengaruhi oleh beberapa faktor, Everall, et al., (Ifdil \& Taufik, 2012) mengemukakan tiga faktor yang mempengaruhi resiliensi individu, antara lain :

1. Faktor individual

Faktor individual merupakan faktor-faktor yang bersumber dari dalam individu itu sendiri, yang mempengaruhi resiliensi meliputi kemampuan kognitif individu, konsep diri, harga diri, dan kompetensi sosial yang dimiliki individu.

2. Faktor keluarga

Faktor keluarga yang berhubungan dengan resiliensi meliputi dukungan orang tua, yaitu bagaimana cara orang tua memperlakukan dan melayani anak. Keterkaitan emosional dan batin antara anggota keluarga sangat diperlukan dalam mendukung pemulihan individu mengalami stress dan trauma. Keterikatan para anggota keluarga amat berpengaruh dalam pemberian dukungan terhadap anggota keluarga yang mengalami musibah untuk dapat pulih dan memandang kejadian tersebut secara objektif. Begitu jug menumbuhkan dan meningkatan resiliensi.

3. Faktor komunitas

Faktor komunitas atau masyarakat sekitar memberikan pengaruh terhadap resiliensi pada diri individu meliputi kemiskinan dan keterbatasan kesempatan kerja.

Dari uraian di atas, dapat disimpulkan resiliensi dipengaruhi oleh faktorfaktor dari dalam individu (internal) dan faktor individu (eksternal). Faktor internal meliputi, kemampuan kognitif, konsep diri, harga diri, dan kompetensi sosial yang dimiliki individu. Faktor eksternal mencakup faktor dari keluarga dan komunitas.

\section{SINGLE MOTHER}

Single mother adalah ibu tunggal atau wanita yang ditinggalkan oleh pasangannya baik karena perceraian ataupun kematian (Aprilia, 2013) dan memutuskan untuk mengasuk anaknya seorang diri atau tunggal (Papalia, Olds, \& Feldman, 2008). (Qaimi, 2003) menyatakan bahwa single mother adalah keadaan wanita yang menjalankan peran ganda sekaligus untuk anak-anaknya. Senada dengan itu (Afdilla, 2017; Pratama, 2014), sebagai orang tua tunggal single mother memegang tanggung jawab untuk melindungi, membimbing dan merawat anaknya seorang diri, tanpa adanya pasangan, disamping itu juga single mother berperan sebagai pencari nafkah dan juga mengurus rumah tangga guna memenuhi kebutuhan psikis anak (Santrock, 2002). Seorang disebut sebagai single mother atau ibu tunggal apabila ia sudah tidak lagi hidup bersama dengan pasangannya, dan pengasuhan anak seluruhnya menjadi tanggung jawab sendiri. Keadaan ini bisa tercipta akibat terjadinya perceraian maupun kematian pasangan.

Dari pernyataan para ahli di atas dapat disimpulkan bahwa single mother adalah seorang ibu tunggal yang mengurus urusan rumah tangga secara sendiri dikarenakan 
perceraian ataupun kematian pasangan, sehingga harus menjalankan peran ganda sebagai ayah dan ibu bagi anak-anaknya.

\section{RESILIENSI SINGLE MOTHER SETELAH KEMATIAN PASANGAN HIDUP}

Resiliensi memiliki peranan yang sangat penting pada diri individu. Resiliensi merupakan kemampuan individu untuk menyesuaikan diri dan beradaptasi terhadap perubahan, tuntutan, dan kekecewaan yang muncul dalam kehidupan. Reivich \& Shatte (Ifdil \& Taufik, 2012) menyatakan bahwa situasi-situasi tertentu, seseorang yang memiliki resiliensi dapat mengatasi berbagai permasalahan kehidupan dengan cara mereka, seperti salah satunya yaitu kehilangan pasangan akibat kematian yang terjadi dan membuat seseorang harus menjadi single parent khususnya single mother.

Kehilangan pasangan merupakan perubahan hidup yang tiba-tiba mengharuskan seseorang melakukan penyesuaian diri dengan keadaan hidupnya yang baru. Perasaan duka cita yang dialami seseorang yang kehilangan pasangan karena kematian berlangsung selama 1 atau 2 tahun setelah kematian pasangan (Kail \& Cavanaugh, 2000). Sejalan dengan pendapat tersebut, Hoyer \& Roodin (2003) mengatakan bahwa individu yang kehilangan seseorang yang dicintai karena kematian akan mengalami perasaan duka cita selama lebih kurang 2 tahun setelah ditinggalkan pasangannya.

Pada hakikatnya tidak ada seorang wanita yang mengingkan dirinya menjadi seorang single mother, namun status ini bisa terjadi pada siapa saja dan kapan saja (Febriyani, Karimah, \& Arista, 2012). Rata-rata dari single mother mereka terkendala dengan anggapan miring lingkungan sekitar mengenai status mereka sebagai orang tua tunggal. Koordinator Nasional Program Pemberdayaan Perempuan Kepala Keluarga (Pekka) Pusat Pengembangan Sumberdaya Wanita (PPSW) (Naufaliasari \& Andriani, 2013) menyatakan bahwa sebutan single mother adalah suatu aib, tanpa memandang peringkat kelas sosial seseorang . Masyarakat cenderung untuk menghina dan memberi label buruk (Newa, 2019) terhadap kaum janda bahkan yang mempunyai anak (single mother) baik akibat bercerai ataupun karena pasangan meninggal tanpa mau melihat faktor penyebab dan berbagai kondisi yang dialami oleh mereka (Zulminarni, 2012)

Tak hanya stigma negatif yang menjadi permasalahan yang dialami oleh seorang single mother, penelitian yang dilakukan oleh Glazer et al., (Naufaliasari \& Andriani, 2013) mengungkapkan bahwa akibat kematian pasangan memberi dampak dalam pengasuhan anak, juga para single mother harus menjalankan peran ganda baik mengasuh maupun mencari nafkah untuk memenuhi tuntutan hidup. Para single mother mengalami tantangan, kesulitan dan cobaan hidup yang datang silih berganti dan harus dihadapi.

Perubahan dan tekanan hidup yang berlangsung begitu intens dan cepat, menjadikan seseorang single mother perlu mengembangkan kemampuan dirinya sedemikian rupa untuk mampu melewati itu semua secara efektif. Dengan memiliki resiliensi dalam diri akan mampu membantu single mother mengambil keputusan dalam kondisi yang sulit secara cepat.

\section{SIMPULAN}

Kondisi dan situasi yang terjadi dalam kehidupan tidak selalu berjalan sesuai dengan harapan manusia. Kematian pasangan hidup merupakan salah satu realitas kehidupan manusia yang sering tidak terelakkan dan dapat memberikan dampak psikologis bagi seseorang yang mengalaminya. Dampak psikologis tersebut antara lain perasaan sedih, tidak siap menjalankan status baru sebagai single mother, dsb. Oleh karena 
itu, resiliensi pada single mother setelah kematian pasangan hidup sangat penting untuk ditingkatkan dan dikembangkan. Peningkatan dan pengembangan ini dapat dilakukan dengan mengidentifikasi awal tingkat resiliensi single mother. Setelah itu dipilih pelayanan konseling yang sesuai guna meningkatkan dan mengembangkan resiliensi tersebut. Tenaga yang berpotensi untuk melakukan pendampingan adalah para konselor profesional.

Dengan demikian para konselor perlu dibekali dengan keterampilan untuk meningkatkan resiliensi single mother, sehingga dampak psikologis setelah kematian pasangan hidup dapat diminimalkan. Salah satu jenis layanan bimbingan dan konseling yang paling tepat diselenggarakan adalah konseling individual.

\section{REFERENSI}

Afdilla, T. (2017). Hubungan Antara Dukungan Orang Tua Tunggal (Ibu) dengan Motivasi Belajar pada Siswa di Pondok Pesantren Mawaridussalam.

Aprilia, W. (2013). Resiliensi dan dukungan sosial pada orang tua tunggal (studi kasus pada ibu tunggal di Samarinda). E-Journal Psikologi, 1(3), 268-279.

Desmita. (2012). Psikologi Perkembangan. Bandung: Remaja Rosdakarya.

Dianthoni, C. K. (2018). RESILIENSI PADA REMAJA BERPRESTASI KORBAN KDRT. Universitas Mercu Buana Yogyakarta.

Fauziyyah, D. (2019). PENERAPAN PENDIDIKAN KARAKTER UNTUK MENINGKATKAN MATA PELAJARAN EKONOMI DI SMAN 1 KEBOMAS. Proceeding National Conference Psikologi UMG 2018, 1(1), 183-190.

Febriyani, S., Karimah, K. El, \& Arista, N. (2012). Dinamika Komunikasi Keluarga Single Mother. Students E-Journal, 1(1).

Grotberg, E. H. (1999). Tapping Your Inner Strength. Oakland, CA: New Harbinger Publication Inc.

Holaday, M. (1997). Resilience and Severe Burns. Journal of Counseling and Development, 75.

Hoyer, W. J., \& Roodin, P. (2003). Adult Development and Aging (5th ed.). New York: McGraw Hill.

Hurlock, B. E. (2011). Psikologi Perkembangan: Suatu Pendekatan Sepanjang Rentang Kehidupan. Jakarta: Erlangga.

Ifdil, \& Taufik. (2012). Upaya Peningkatan dan Pengembangan Resiliensi Siswa di Sumatera Barat. Pedagogi Jurnal Ilmiah Ilmu Pendidikan, XII(2), 115-121.

Kail, \& Cavanaugh. (2000). Human Development: A Life Span View. USA: Wadswoth.

Kisworowati, N. (2010). Strategi Coping Ibu Dalam Menjalani Peran Sebagai Orang Tua Tunggal. Universitas Muhammadiyah Surakarta.

Lestari, F. A., \& Mariyati, L. I. (2016). Resiliensi ibu yang memiliki anak down syndrome di Sidoarjo. Psikologia: Jurnal Psikologi, 3(1), 141-155.

Naufaliasari, A., \& Andriani, F. (2013). Resiliensi pada Wanita Dewasa Awal Pasca Kematian Pasangan. Jurnal Psikologi Industri Dan Organisasi, 2(2).

Newa, I. (2019). Hubungan Antara Self Esteem Dengan Resiliensi Pada Single Mother. Universitas Mercu Buana Yogyakarta.

Novianti, D. (2018). Kontribusi Atmosfer Keluarga Terhadap Resiliensi Lansia Penderita Penyakit Degeneratif Di Kota Bekasi Utara. UNIVERSITAS NEGERI JAKARTA.

Papalia, D. E., Olds, S. W., \& Feldman, R. D. (2008). Human Development. Jakarta: Prenada 


\section{Media Group.}

Pratama, B. E. (2014). Resiliensi di rumah tangga pada ibu sebagai orang tua tunggal. Universitas Muhammadiyah Surakarta.

Pratitasari, I. (2016). Studi Komparatif Mengenai Resiliensi Remaja Korban Sodomi Di Desa Jelekong Dan Di Desa Cangkuang Kulon Kabupaten Bandung.

Qaimi, A. (2003). Single Parent: Peran ganda ibu dalam mendidik anak. Bogor: Cahaya.

Ririn, N. (2018). Layanan Konseling Kelompok Dalam Meningkatkan Resiliensi Anak Korban Banjir. UIN Sunan Gunung Djati Bandung.

Santrock, W. J. (2002). Life-span Development : Perkembangan Masa Hidup. Jakarta: Erlangga.

SETYANINGRUM, L. (2018). HUBUNGAN ANTARA RESILIENSI DENGAN KESEJAHTERAAN PSIKOLOGIS PADA ORANGTUA YANG MEMILIKI ANAK DISABILITAS INTELEKTUAL DI SLB C DAN C1 YAKUT PURWOKERTO. UNIVERSITAS MUHAMMADIYAH PURWOKERTO.

Shochib, M. (2000). Pola Asuh Orang Tua dalam Membantu Anak Mengembangkan Disiplin Diri. Jakarta: Rineka Cipta.

W.J.S. Poerwadarminta. (2009). Kamus Umum Bahasa Indonesia. Jakarta: Balai Pustaka.

Zulminarni, N. (2012). Dunia Tanpa Suami: Perempuan Kepala Keluarga sebagai Realitas yang Tidak Tercatat. Jurnal Perempuan. 